\title{
Calcium-induced chloride secretion is decreased by Resveratrol in ileal porcine tissue
}

\author{
Susanne Hoppe, Gerhard Breves and Stefanie Klinger * (1)
}

\begin{abstract}
Objective: Chloride $\left(\mathrm{Cl}^{-}\right)$secretion is crucial for intestinal fluid secretion. Therefore, effects of the polyphenol Resveratrol (RSV) on $\mathrm{Cl}^{-}$secretion have been investigated. In a previous study, we observed effects of RSV on forskolininduced $\mathrm{Cl}^{-}$secretion in the porcine jejunum but not the ileum although RSV itself induced a transepithelial ion current that may represent $\mathrm{Cl}^{-}$secretion in the ileum. The aim of this study was to gain further insights regarding the effects of RSV on characteristics of $\mathrm{Cl}^{-}$secretion in the porcine ileum using the Ussing chamber technique (recording of short circuit currents $\left(I_{s c}\right)$ as a measure for epithelial net ion transfer).

Results: RSV increased the $I_{S c}$ in the porcine ileum but not in the porcine jejunum as is already known. This increase was absent in a $\mathrm{Cl}^{-}$-free buffer system, indicating that RSV indeed induces $\mathrm{Cl}^{-}$secretion. However, the carbacholinduced $\mathrm{I}_{\mathrm{sc}}$ was significantly inhibited by RSV indicating an inhibition of $\mathrm{Ca}^{2+}$-induced $\mathrm{Cl}^{-}$secretion. The cellular basis for these contradictory, segment specific results of RSV on $\mathrm{Cl}^{-}$secretion has to be subjected to further studies. The results also underline, that is difficult to generalize effects of RSV between different intestinal locations, organs, cell culture models or species.
\end{abstract}

Keywords: CALCIUM, CAMP, Carbachol, Chloride secretion, CFTR, Resveratrol, Short circuit currents, Ussing chamber

\section{Introduction}

Chloride $\left(\mathrm{Cl}^{-}\right)$secretion is crucial for intestinal fluid balance since it controls the water transport into the gut lumen and is thus involved in the development of secretory diarrhea. Reduced $\mathrm{Cl}^{-}$secretion decreases water movement into the gut lumen and can thus result in thickened mucus as e.g. in cystic fibrosis.

In secretory epithelia as the intestinal mucosa, $\mathrm{Cl}^{-}$ secretion is mainly mediated by cystic fibrosis transmembrane conductance regulator (CFTR) which is regulated by intracellular cyclic adenosine monophosphate (cAMP). A second potential mechanism are the intracellular $\mathrm{Ca}^{2+}$ levels $\left(\mathrm{Ca}_{\mathrm{i}}^{2+}\right)[1,2]$. Besides CFTR, $\mathrm{Ca}^{2+}$-activated $\mathrm{Cl}^{-}$channels $(\mathrm{CaCC})$ are a further mechanism for $\mathrm{Cl}^{-}$secretion [2]. $\mathrm{Ca}_{\mathrm{i}}^{2+}$ may also enhance the

\footnotetext{
*Correspondence: stefanie.klinger@tiho-hannover.de Department of Physiology, University of Veterinary Medicine Hannover, Foundation, Bischofsholer Damm 15, 30173 Hannover, Germany
}

driving force for chloride secretion via activating $\mathrm{K}^{+}$ channels [3, 4].

The polyphenol Resveratrol (RSV) is able to affect cAMP and $\mathrm{Ca}_{i}^{2+}$ levels. RSV elevates cAMP levels via inhibiting phosphodiesterases and stimulating adenylate cyclase [5-7]. Increased $\mathrm{Ca}_{\mathrm{i}}^{2+}$ levels were described in different tissues and cell models (e.g. vascular smooth muscle cells [8], mesothelioma cell lines [9], primary dermal fibroblasts [10] or cortical neurons [11]) but the effects were based on different mechanisms (influx from intra- or extracellular stores [8, 9], efflux inhibition [10], intracellular signalling [11]).

The effects of RSV on $\mathrm{Cl}^{-}$secretion have been investigated with regard to improve the function of CFTR or the deltaF508 mutation as involved in cystic fibrosis. Activating effects were e.g. described for sinonasal epithelial cells [12, 13], a pancreatic cell line [14] and rat colonocytes [15]. Other studies failed to demonstrate effects 
which is discussed with regards to the models and the concentration of RSV [16, 17].

The concentration is of particular interest since the bioavailability of RSV is low so that most cells within an organism are most likely not exposed to concentrations exceeding the low micro molar range [18]. The only organ that may be exposed to higher concentrations is the small intestine due to high RSV contents in dietary supplements. Regarding the small intestine less is known about effects of RSV on $\mathrm{Cl}^{-}$secretion.

Effects of RSV on intestinal cAMP-mediated $\mathrm{Cl}^{-}$ secretion have been described by Blumenstein et al. [19] for mouse jejunum and the epithelial cell line T84. By applying the Ussing chamber technique it could be demonstrated that RSV increased the $I_{s c}$ (a measure of electrogenic ion transport) only in the presence of $\mathrm{Cl}^{-}$[19]. RSV dimers were found to decrease CaCCmediated currents in the epithelial cell line HT-29 and in the murine colon [20]. To our knowledge, there is only one publication that showed an effect of RSV on $\mathrm{Ca}^{2+}$-induced $\mathrm{Cl}^{-}$secretion [21].

In a recent study [22], we investigated the effects of RSV on intestinal transport using porcine jejunal and ileal samples in Ussing chamber experiments. After incubation with RSV, porcine jejunal tissues showed a decreased $I_{s c}$ while the ileum showed an increased $I_{s c}$. This indicates differences between the inducibility of $\mathrm{Cl}^{-}$ secretion by RSV between the segments but it was not possible to evaluate whether these effects were mediated by $\mathrm{Cl}^{-}$secretion. Interestingly, the increased $\mathrm{I}_{\mathrm{sc}}$ occurred not in the jejunum as observed by Blumenstein et al. but in the ileum. In the study of Blumenstein et al. [19] forskolin (activator of cAMP-mediated $\mathrm{Cl}^{-}$secretion), further increased the $I_{s c}$ after RSV stimulation of jejunal tissues while we failed to induce a further increase in ileal tissues.

Based on these results the present study aimed at verifying that the RSV-mediated increase in $\mathrm{I}_{\mathrm{sc}}$ in ileal tissue was due to $\mathrm{Cl}^{-}$secretion. Additionally we aimed at getting first indications whether there is an effect of RSV on $\mathrm{Ca}^{2+}$-induced $\mathrm{Cl}^{-}$secretion by measuring the effects of carbachol, which increases $\mathrm{Ca}_{\mathrm{i}}^{2+}$, after incubation with RSV.

\section{Main text}

\section{Materials and methods}

\section{Animals and tissue removal}

Thirteen piglets (Sus scrofa domestica, German Landrace $\times$ Large White) kept on a conventional diet with free access to water were used. Four animals were used for the preliminary set of experiments and nine animals for the main experiments. The pigs were slaughtered by stunning with subsequent carotid artery bleeding.
Tissues were removed, rinsed with cold saline $\left(4{ }^{\circ} \mathrm{C}\right)$ and stored in serosal buffer (Additional file 1: Table S1) for Ussing chamber experiments.

\section{Ussing chamber experiments}

The Ussing chamber technique [23] is a in vitro setup for measuring transport processes across intact epithelia. The mucosal and serosal compartments are filled with different buffers (Fig. 1, Additional file 1: Table S1). The movement of ions across a membrane produces a potential difference. Under the applied short circuit conditions, the transepithelial potential difference (PD) is set to $0 \mathrm{mV}$ using a voltage clamp devise (EC-285, Warner Instruments). The current that is necessary for setting PD to $0 \mathrm{mV}$ is called the short circuit current $\left(\mathrm{I}_{\mathrm{sc}}\right)$ and is a measure for the transepithelial net ion transfer.

Jejunal (third meter distal to the pylorus) and ileal (first meter proximal to the ileocaecal valve, first $30 \mathrm{~cm}$ discarded) samples were mounted in Ussing chambers (four chambers/animal, serosal area: $1 \mathrm{~cm}^{2}$ ). The tissue conductance $\left(G_{t}\right)$ was assessed by stimulations $(0.1$ pps, $500 \mathrm{~ms}, 150 \mathrm{mV}$, ten times, Stimulator S48, Grass Technologies) at the beginning of the experiments and between all additions. Figure 1 explains the detailed experiment setup.

In a so far unpublished preliminary set of experiments using jejunal and ileal samples from four animals, it was tested whether the carbachol-induced $\Delta \mathrm{I}_{\mathrm{sc}}$

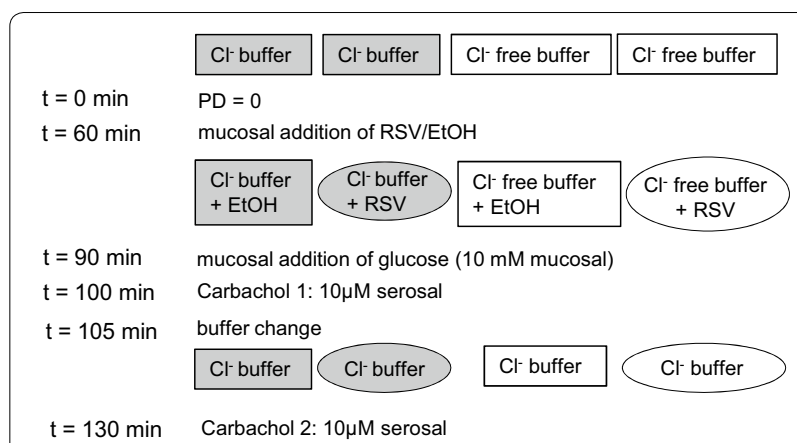

Fig. 1 Schematic illustration of the experimental setup for Ussing chamber experiments. The composition of the serosal and mucosal buffer solutions with or without chloride is given in Additional file 1: Table S1. After an equilibration period with chloride-containing or chloride-free buffer solutions, RSV (Sigma-Aldrich, $300 \mu \mathrm{M}$ ) or ethanol (control, $20 \mu \mathrm{l} / 10 \mathrm{ml}$ ) were added to the mucosal compartment. After $30 \mathrm{~min}$, glucose (10 mM mucosal) was applied in order to induce $\mathrm{Na}^{+}$-coupled glucose transport which is known to be inhibited by RSV [22, 25]. After another $10 \mathrm{~min}$, carbachol $(10 \mu \mathrm{M}$ serosal, Sigma-Aldrich) was added to stimulate $\mathrm{Ca}^{2+}{ }^{2}$-induced $\mathrm{Cl}^{-}$secretion ( $\Delta \mathrm{I}_{\mathrm{sc}}$ carbachol 1) [3]. The buffers were changed to chloride-containing buffers in all chambers and carbachol was added once again ( $\Delta \mathrm{I}_{\mathrm{sc}}$ carbachol 2 ). Mucosal additions exceeding $1 \mathrm{mM}$ were osmotically balanced by the serosal addition of mannitol (non-absorbable, non metabolisable sugar) 
is modulated by RSV. No effect was observed for jejunal tissues $\left(\Delta \mathrm{I}_{\mathrm{sc}}\right.$ carbachol $\left(\mu \mathrm{A} \cdot \mathrm{cm}^{-2}\right)$ : crtl: $24.27 \pm 11.52$, RSV: $20.88 \pm 6.62$ ) while $\Delta \mathrm{I}_{\mathrm{sc}}$ carbachol for ileal tissues was decreased (crtl: $31.15 \pm 4.09$, RSV: $20.53 \pm 4.49$, $\mathrm{p}=0.0237$ ). Therefore, ileal tissues were used in the main experiments.

\section{Data analysis and statistics}

$\Delta \mathrm{I}_{\mathrm{sc}}$ was calculated as the difference of the $\mathrm{I}_{\mathrm{sc}}$ before an addition and the maximal $\mathrm{I}_{\mathrm{sc}}$ afterwards. Gaussian distribution was tested (Shapiro-Wilk normality test). In case of Gaussian distribution, RM one-way ANOVA and Fisher's LSD test were used. Otherwise, Friedman test and uncorrected Dunn's test were used. All these analyses were done with GraphPad Prism 7.04. The power for the RM one-way ANOVA was estimated a priori to be 0.71 ( $\mathrm{n}=8$ animals) using $\mathrm{G}^{*}$ Power 3 [24]. When RM one-way

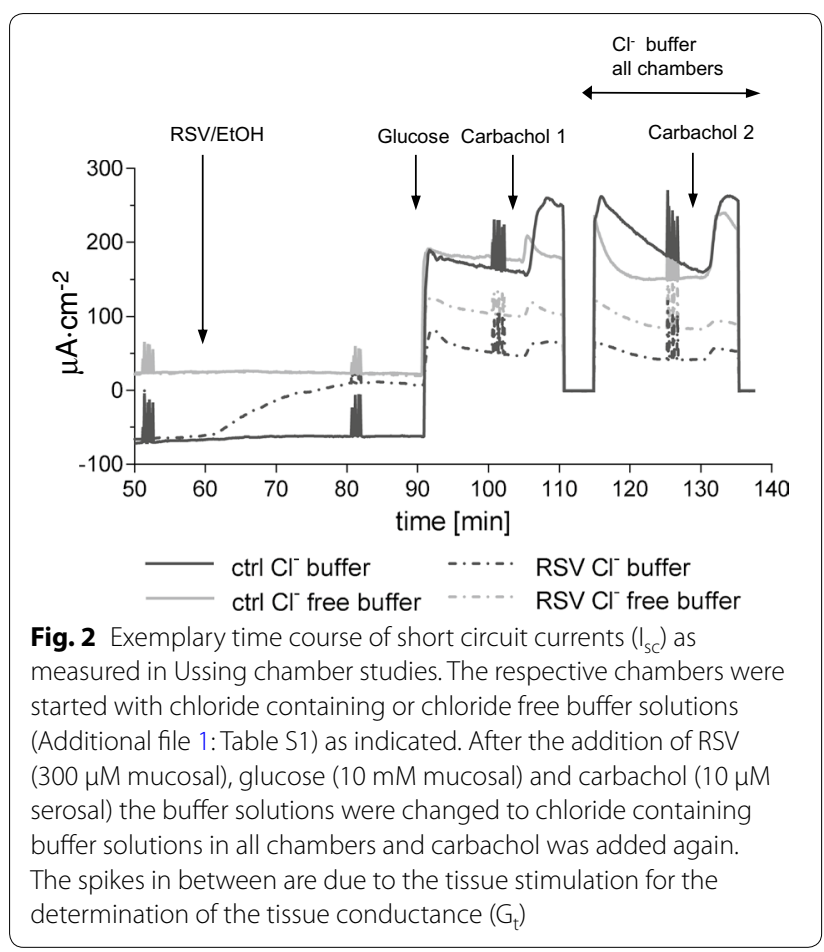

ANOVA was used, the post hoc calculated power $(n=9)$ is given in the legend to Fig. 3. Due to the high effect size, the actual power of the parametric procedure was higher as calculated a priori what indicates sufficient power for the nonparametric procedures.

\section{Results and discussion}

Figure 2 shows an exemplary course of the $I_{s c}$. Means and the statistical analysis are shown in Fig. 3. $G_{t}$ (in $\mathrm{mS} \mathrm{cm}{ }^{-2}$ ) was not changed after most additions. Differences could only be observed between chambers with $\mathrm{Cl}^{-}$and $\mathrm{Cl}^{-}$-free buffers $\left(\mathrm{Cl}^{-}: 19.4 \pm 2.18, \mathrm{Cl}^{-}\right.$free: $14.8 \pm 1.26, \mathrm{p}=0.0007)$. Glucose caused a slight increase in $\mathrm{G}_{\mathrm{t}}$ in $\mathrm{Cl}^{-}$-containing chambers irrespective of RSV $\left(\mathrm{ctrl} / \mathrm{Cl}^{-}: 2.89 \pm 2.53, \mathrm{RSV} / \mathrm{Cl}^{-}: 3.02 \pm 2.95\right)$.

As shown in Fig. 3a, $I_{s c}$ was increased by RSV $(\mathrm{p}=0.029)$ what validates the results from our previous study [22]. Since this increase was absent under $\mathrm{Cl}^{-}$-free conditions $(p=0.0001)$, this part of the study confirms, that the $\mathrm{RSV}$-mediated increase is caused by $\mathrm{Cl}^{-}$secretion as it was speculated.

As shown in Fig. 3b, RSV decreased the glucoseinduced $\Delta \mathrm{I}_{\mathrm{sc}}(\mathrm{p}=0.002)$, what is already known from our previous studies [22, 25]. Additionally, this part of the study may give some new indications that RSV may affect $\mathrm{Ca}^{2+}$-induced $\mathrm{Cl}^{-}$secretion since the glucose-induced $\mathrm{I}_{\mathrm{sc}}$ for $\mathrm{ctrl} / \mathrm{Cl}^{-}$-free chambers was decreased compared to $\mathrm{ctrl} / \mathrm{Cl}^{-}$chambers $(\mathrm{p}=0.014)$. It has been shown that glucose stimulates $\mathrm{Ca}^{2+}$-induced $\mathrm{Cl}^{-}$secretion in intestinal cells $[26,27]$. Therefore, this difference may indicate that a part of the $\Delta \mathrm{I}_{\mathrm{sc}}$ under control conditions may be due to glucose-mediated stimulation of $\mathrm{Ca}^{2+}$-induced $\mathrm{Cl}^{-}$secretion especially since there is a correlation between the glucose-induced $\Delta \mathrm{I}_{\mathrm{sc}}$ under ctrl and $\mathrm{Cl}^{-}$-free conditions $\left(R^{2}=0.846, p=0.0004\right)$. Nevertheless, there is still a difference between the glucose-induced $\Delta \mathrm{I}_{\mathrm{sc}}$ in $\mathrm{Cl}^{-}$-free control chambers and $\mathrm{RSV} / \mathrm{Cl}^{-}$-free chambers $(\mathrm{p}=0.0066)$, while the $\Delta \mathrm{I}_{\mathrm{sc}}$ for RSV-treated tissues does not depend on the presence of $\mathrm{Cl}^{-}(\mathrm{p}=0.577)$.

Taken together, the results in Fig. 3b confirm the inhibition of $\mathrm{Na}^{+}$-coupled glucose transport by RSV and

(See figure on next page.)

Fig. 3 Changes in short circuit currents $\left(\Delta \mathrm{I}_{\mathrm{sc}} \mu \mathrm{A} \cdot \mathrm{cm}^{-2}\right)$ as measured in Ussing chamber experiments using porcine ileal tissues and chloride containing and chloride free buffer solutions in the mucosal and serosal compartments. a $\triangle \mathrm{I}_{\mathrm{sc}}$ after the addition of Resveratrol (RSV, $300 \mu \mathrm{M}$ mucosal). $\mathbf{b} \Delta \mathrm{I}_{\mathrm{sc}}$ after the addition of glucose (10 mM mucosal, $10 \mathrm{mM}$ mannit serosal). $\mathbf{c} \Delta \mathrm{I}_{\mathrm{sc}}$ after the first addition of carbachol (10 $\mu \mathrm{M}$, serosal). d $\Delta \mathrm{I}_{\mathrm{sc}}$ after the second addition of carbachol $(10 \mu \mathrm{M}$, serosal) after the chloride free buffer solutions were replaced by chloride containing buffer solutions. e direct comparison of $\Delta \mathrm{I}_{\mathrm{sc}}$ caused by carbachol under chloride free conditions and after changing the buffers to chloride containing standard buffers. Statistic results of the respective analysis of variance are shown below the graph and the results of the post test (Fisher's LSD after RM one-way ANOVA and uncorrected Dunn's test after the Friedman test) are indicated with asterisks: ${ }^{*} p \leq 0.05,{ }^{* *} p \leq 0.01,{ }^{* * *} p \leq 0.001$. For the parametric test procedures in $\mathbf{b}$ and $\mathbf{c}$, the statistical power was calculated $\mathbf{b}$ : Power of $0.89\left(\eta^{2}=0.26\right.$, effect size for treatment $\left.f=0.59\right)$; $\mathbf{c}$ : Power of $0.99\left(\eta^{2}=0.61, f=1.26\right)$. Mean $\pm S D$ are given in Additional file 2: Table S2 

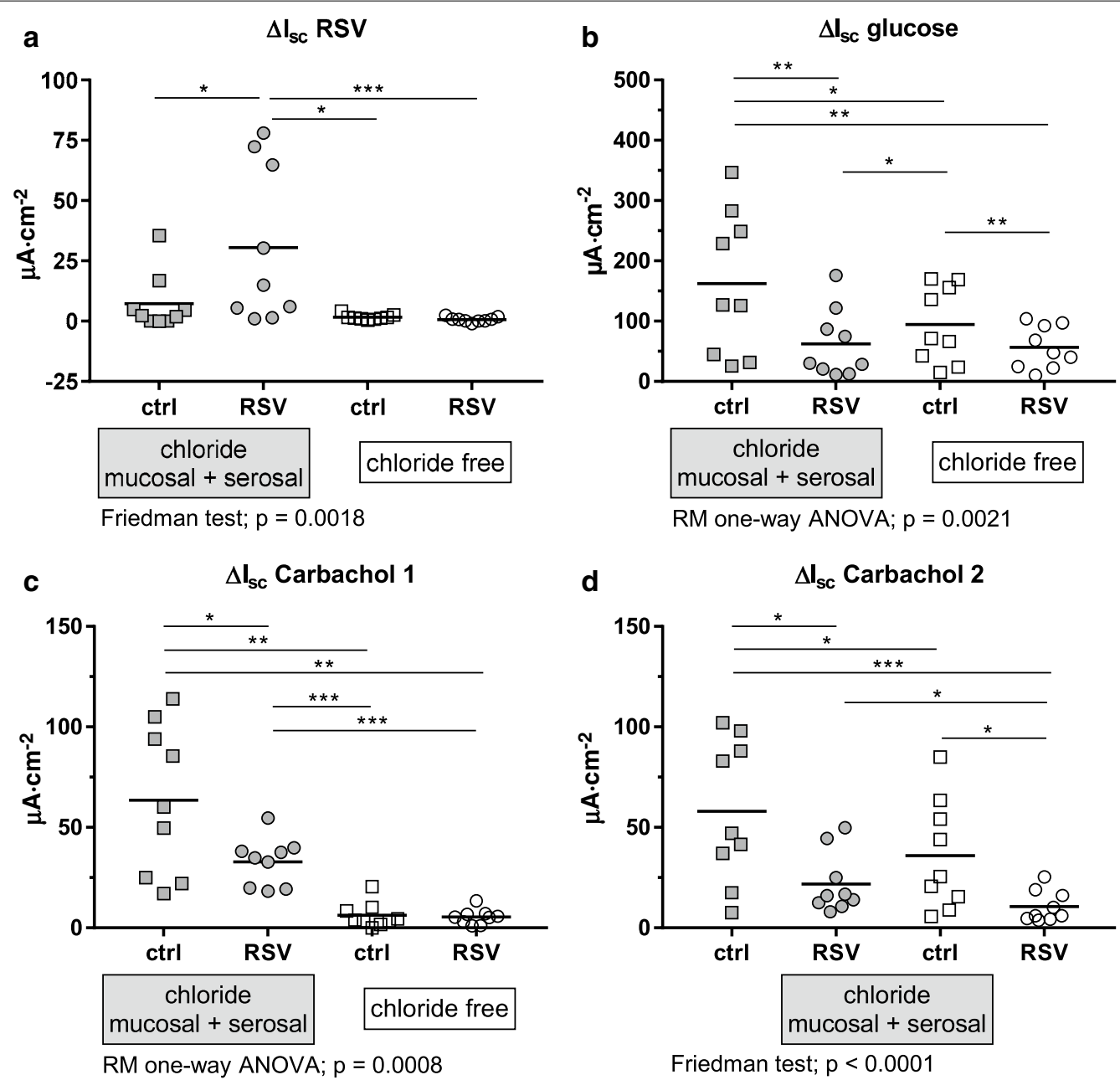
e $\Delta \mathrm{l}_{\mathrm{sc}}$ Carbachol after $\mathrm{Cl}^{-}$addition
e to formerly $\mathrm{Cl}^{-}$free chambers

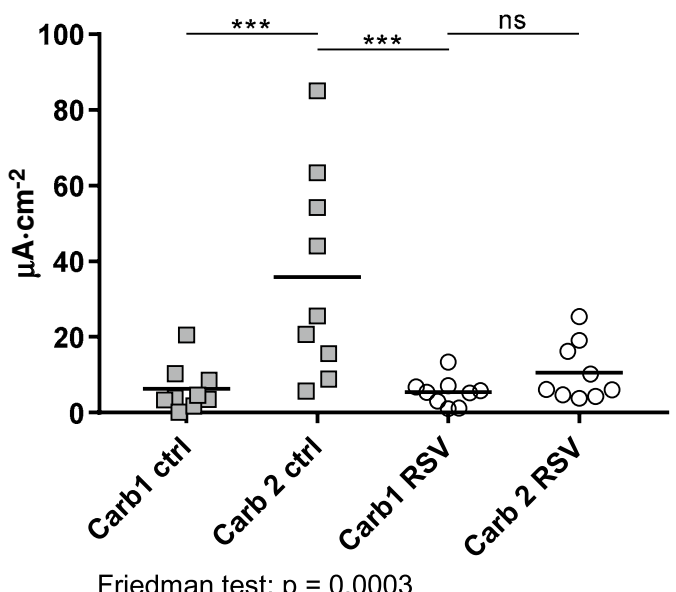

$\square$ ctrl $\mathrm{Cl}^{-}$buffer

O RSV Cl- buffer

$\square$ ctrl $\mathrm{Cl}^{-}$free buffer

O RSV $\mathrm{Cl}^{-}$free buffer

Friedman test; $p=0.0003$ 
point to an inhibitory potential with regard to glucosestimulated $\mathrm{Ca}^{2+}$-induced $\mathrm{Cl}^{-}$secretion.

This is strengthened by the data in Fig. $3 \mathrm{c}, \mathrm{d}$ and e. In the presence of $\mathrm{Cl}^{-}$, the carbachol-induced $\Delta \mathrm{I}_{\mathrm{sc}}$ was decreased after RSV treatment $(\mathrm{p}=0.034)$. Without $\mathrm{Cl}^{-}$, a response to carbachol was observed neither in control nor in RSV-treated chambers. The difference between the RSV-treated chambers with and without $\mathrm{Cl}^{-}(\mathrm{p}=0.0004)$ may indicate an incomplete inhibition of $\mathrm{Ca}^{2+}$-dependent $\mathrm{Cl}^{-}$secretion. After the buffer solutions were changed to chloride-containing buffer in all chambers and carbachol was added again $\left(\Delta \mathrm{I}_{\mathrm{sc}}\right.$ carbachol 2, Fig. 3d) the formerly $\mathrm{Cl}^{-}$-free chambers responded in a similar way as the $\mathrm{Cl}^{-}$-containing chambers. The responses in the chambers with $\mathrm{Cl}^{-}$during the whole experiment were still higher than in the former $\mathrm{Cl}^{-}$-free chambers but the differences were less pronounced compared to $\Delta \mathrm{I}_{\mathrm{sc}}$ carbachol 1 . Figure $3 \mathrm{e}$ also clearly shows, that the response to carbachol is restored in control chambers after the readdition of $\mathrm{Cl}^{-}(\mathrm{p}=0.0003)$. This is not the case for RSV-treated chambers $(\mathrm{p}=0.1441)$.

In summary, the results of the present study demonstrate that RSV (1) induces chloride secretion and (2) inhibits $\mathrm{Ca}^{2+}$-induced $\mathrm{Cl}^{-}$secretion in the porcine ileum.

This raises the question what the basis for the RSVinduced $\mathrm{Cl}^{-}$secretion is. This could not finally be elucidated from the present data but it seems reasonable to assume that a cAMP-mediated activation of CFTR may be the reason for the RSV-induced $\mathrm{Cl}^{-}$secretion as it was the case in the murine jejunum [19]. If the observed $\mathrm{Cl}^{-}$ secretion would be due to CFTR activation, this might explain why RSV had no effect on ileal forskolin-induced $\mathrm{I}_{\mathrm{sc}}$ in our previous study [22], when assuming that CFTR is working at its maximal capacity after activation by RSV.

The inhibitory effect of RSV on $\mathrm{Ca}^{2+}$-induced $\mathrm{Cl}^{-}$ secretion is, with regard to the ability of RSV to increase $\mathrm{Ca}_{\mathrm{i}}^{2+}$, a surprising finding but to our knowledge, $\mathrm{Ca}_{\mathrm{i}}^{2+}$ after short time exposure to RSV has never been measured in enterocytes. It has to be questioned, at which stage RSV affects the action of carbachol. Firstly, RSV may not lead to increased $\mathrm{Ca}_{\mathrm{i}}^{2+}$ but rather inhibit the carbachol-induced increase in $\mathrm{Ca}_{\mathrm{i}}^{2+}$ since it has been shown in Caco- 2 cells, that RSV prevents $\mathrm{Ca}^{2+}$ mobilization from the endoplasmic reticulum that was induced by the non-steroidal anti-inflammatory drug indomethacin [28]. Secondly, inhibitory effects on $\mathrm{K}^{+}$channels may be discussed but assuming this, the RSV-evoked basal $\mathrm{Cl}^{-}$ secretion is difficult to explain. Also direct RSV-transporter interactions may be involved as discussed for the activating effects on the CaCC TMEM16A [21].

In conclusion, it has to be noted that the effects of RSV on intestinal chloride secretion are different between the proximal and distal parts of the small intestines. In addition, both cAMP- and $\mathrm{Ca}^{2+}$-mediated chloride secretion is involved and is affected differently. These complex effects should be subjected to further studies since they may contribute to develop a concept about the variety of effects that RSV exerts in different organs or cell culture models. In any case, it becomes increasingly clear, that it is difficult to generalize effects of RSV between intestinal locations, organs, cell culture models or species.

\section{Limitations}

The Ussing chamber technique as applied in the present study only gives information about changes in the transepithelial net ion transfer. Under the experimental conditions it is not possible to distinguish between the movements of different ions. Therefore, it is not possible to evaluate whether $\mathrm{Ca}^{2+}$ is still able to the cell after incubation with RSV or whether changes in the $\mathrm{K}^{+}$conductance of the membrane are involved in the observed effects. This limits the significance of the study with regard to mechanistic aspects.

\section{Additional files}

Additional file 1. Composition of buffer solutions for Ussing chamber experiments.

Additional file 2. Means \pm standard deviation for the data shown in Fig. 3 as dot plots with means only.

\section{Abbreviations \\ $\mathrm{Ca}^{2+}$ : calcium; $\mathrm{Ca}_{i}^{2+}$ : intracellular calcium concentration; $\mathrm{CaCC}: \mathrm{Ca}^{2+}$ activated $\mathrm{Cl}^{-}$channel; CAMP: cyclic adenosine monophosphate; CFTR: cystic fibrosis transmembrane conductance regulator; $\mathrm{Cl}^{-}$: chloride; $\mathrm{G}_{t}$ : tissue conductance; $\mathrm{I}_{\text {sc }}$ : short circuit current; $\mathrm{K}^{+}$: potassium; RSV: Resveratrol.}

\section{Authors' contributions}

SH planned and carried out the Ussing chamber experiments and acquired and analyzed the data. GB substantially contributed to the interpretation and discussion of the results by critically editing and revising the manuscript. SK conceived and planned the research including funding acquisition, took the samples, did the statistical analysis, interpreted and discussed the data and drafted and wrote the manuscript. All authors read and approved the final manuscript.

\section{Acknowledgements}

The authors wish to thank Yvonne Armbrecht and Michael Rohde for animal care.

\section{Competing interests}

The authors declare that they have no competing interests.

\section{Availability of data and materials}

All data that was generated and analyzed in this study are available from the corresponding author on reasonable request.

Consent for publication

Not applicable. 


\section{Ethics approval and consent to participate}

All animals received care according to the German Animal Protection Law which complies with the EC Directive 2010/63/EU. According to the German Animal Protection Law (TierSchG §7, Section 2) the experimental procedure described in the present study (slaughter and tissue removal for scientific purposes without any treatments or interventions prior to slaughter) is not classified as an animal experiment.

Therefore, no approval by the Animal Care and Use Committee is required and no reference numbers are provided. According to the German Animal Protection Law (TierSchG) and the German Regulation on the Reporting of Laboratory Animals (VersTierMeldV), the killing of the animals has to be announced to the university's animal welfare officer what was done on $28 / 08 / 2015$ and the required annual report regarding the number of animals used per year was done according to the VersTierMeldV.

\section{Funding}

This work was supported by the German Research Foundation (DFG; Grant Number KL 2882/2-1).

\section{Publisher's Note}

Springer Nature remains neutral with regard to jurisdictional claims in published maps and institutional affiliations.

Received: 23 July 2018 Accepted: 8 October 2018

Published online: 11 October 2018

\section{References}

1. Billet A, Hanrahan JW. The secret life of CFTR as a calcium-activated chloride channel. J Physiol. 2013;591(21):5273-8.

2. Kunzelmann K, Mehta A. CFTR: a hub for kinases and crosstalk of CAMP and $\mathrm{Ca}^{2+}$. FEBS J. 2013;280(18):4417-29.

3. Dharmsathaphorn K, Pandol SJ. Mechanism of chloride secretion induced by carbachol in a colonic epithelial cell line. J Clin Investig. 1986;77(2):348-54.

4. Barrett KE, Keely SJ. Chloride secretion by the intestinal epithelium: molecular basis and regulatory aspects. Annu Rev Physiol. 2000;62:535-72.

5. Park SJ, Ahmad F, Philp A, Baar K, Williams T, Luo H, et al. Resveratrol ameliorates aging-related metabolic phenotypes by inhibiting CAMP phosphodiesterases. Cell. 2012;148(3):421-33.

6. El-Mowafy AM, Alkhalaf M. Resveratrol activates adenylyl-cyclase in human breast cancer cells: a novel, estrogen receptor-independent cytostatic mechanism. Carcinogenesis. 2003;24(5):869-73.

7. Zhang Y, Chen ML, Zhou Y, Yi L, Gao YX, Ran L, et al. Resveratrol improves hepatic steatosis by inducing autophagy through the CAMP signaling pathway. Mol Nutr Food Res. 2015;59(8):1443-57.

8. Campos-Toimil M, Elies J, Orallo F. Trans- and cis-resveratrol increase cytoplasmic calcium levels in A7r5 vascular smooth muscle cells. Mol Nutr Food Res. 2005:49(5):396-404.

9. Marchetti C, Ribulla S, Magnelli V, Patrone M, Burlando B. Resveratrol induces intracellular $\mathrm{Ca}(2+)$ rise via T-type $\mathrm{Ca}(2+)$ channels in a mesothelioma cell line. Life Sci. 2016;148:125-31.

10. Peterson JA, Oblad RV, Mecham JC, Kenealey JD. Resveratrol inhibits plasma membrane $\mathrm{Ca}(2+)$-ATPase inducing an increase in cytoplasmic calcium. Biochem Biophys Rep. 2016;7:253-8.

11. Zhang JQ, Wu PF, Long LH, Chen Y, Hu ZL, Ni L, et al. Resveratrol promotes cellular glucose utilization in primary cultured cortical neurons via calcium-dependent signaling pathway. J Nutr Biochem. 2013;24(4):629-37.
12. Zhang S, Blount AC, McNicholas CM, Skinner DF, Chestnut M, Kappes $J$, et al. Resveratrol enhances airway surface liquid depth in sinonasal epithelium by increasing cystic fibrosis transmembrane conductance regulator open probability. PLoS ONE. 2013;8(11):e81589.

13. Woodworth BA. Resveratrol ameliorates abnormalities of fluid and electrolyte secretion in a hypoxia-Induced model of acquired CFTR deficiency. Laryngoscope. 2015;125(Suppl 7):S1-13.

14. Hamdaoui N, Baudoin-Legros M, Kelly M, Aissat A, Moriceau S, Vieu DL, et al. Resveratrol rescues CAMP-dependent anionic transport in the cystic fibrosis pancreatic cell line CFPAC1. Br J Pharmacol. 2011;163(4):876-86.

15. Yang S, Yu BO, Sui Y, Zhang Y, Wang X, Hou S, et al. CFTR chloride channel is a molecular target of the natural cancer preventive agent resveratrol. Pharmazie. 2013;68(9):772-6.

16. Dey I, Shah K, Bradbury NA. Natural compounds as therapeutic agents in the treatment cystic fibrosis. J Genet Syndr Gene Ther. 2016;7(1):284.

17. Jai Y, Shah K, Bridges RJ, Bradbury NA. Evidence against resveratrol as a viable therapy for the rescue of defective DeltaF508 CFTR. Biochim Biophys Acta. 2015:1850(11):2377-84.

18. Walle T, Hsieh F, DeLegge MH, Oatis JE Jr, Walle UK. High absorption but very low bioavailability of oral resveratrol in humans. Drug Metab Dispos. 2004;32(12):1377-82.

19. Blumenstein I, Keseru B, Wolter F, Stein J. The chemopreventive agent resveratrol stimulates cyclic AMP-dependent chloride secretion in vitro. Clin Cancer Res. 2005;11(15):5651-6.

20. Yu B, Jiang Y, Zhang B, Yang H, Ma T. Resveratrol dimer trans-epsilonviniferin prevents rotaviral diarrhea in mice by inhibition of the intestinal calcium-activated chloride channel. Pharmacol Res. 2018;129:453-61.

21. Chai R, Chen Y, Yuan H, Wang X, Guo S, Qi J, et al. Identification of resveratrol, an herbal compound, as an activator of the calcium-activated chloride channel, TMEM16A. J Membr Biol. 2017;250(5):483-92.

22. Klinger $S$, Breves $G$. Resveratrol inhibits porcine intestinal glucose and alanine transport: potential roles of $\mathrm{Na}(+) / \mathrm{K}(+)$-ATPase activity, protein kinase A, AMP-activated protein kinase and the association of selected nutrient transport proteins with detergent resistant membranes. Nutrients. 2018;10(3):302.

23. Ussing HH, Zerahn K. Active transport of sodium as the source of electric current in the short-circuited isolated frog skin. Acta Physiol Scand. 1951;23(2-3):110-27.

24. Faul F, Erdfelder E, Lang AG, Buchner A. G*Power 3: a flexible statistical power analysis program for the social, behavioral, and biomedical sciences. Behav Res Methods. 2007;39(2):175-91.

25. Guschlbauer M, Klinger S, Burmester M, Horn J, Kulling SE, Breves G. transResveratrol and epsilon-viniferin decrease glucose absorption in porcine jejunum and ileum in vitro. Comp Biochem Physiol. 2013;165(3):313-8.

26. Yin L, Vijaygopal P, MacGregor GG, Menon R, Ranganathan P, Prabhakaran $\mathrm{S}$, et al. Glucose stimulates calcium-activated chloride secretion in small intestinal cells. Am J Physiol Cell Physiol. 2014;306(7):C687-96.

27. Binder HJ, Powell DW, Curran PF. Effect of hexoses on ion transport in guinea pig ileum. Am J Physiol. 1972;223(3):538-44.

28. Carrasco-Pozo C, Pastene E, Vergara C, Zapata M, Sandoval C, Gotteland M. Stimulation of cytosolic and mitochondrial calcium mobilization by indomethacin in Caco-2 cells: modulation by the polyphenols quercetin, resveratrol and rutin. Biochim Biophys Acta. 2012;1820(12):2052-61.

Ready to submit your research? Choose BMC and benefit from:

- fast, convenient online submission

- thorough peer review by experienced researchers in your field

- rapid publication on acceptance

- support for research data, including large and complex data types

- gold Open Access which fosters wider collaboration and increased citations

- maximum visibility for your research: over 100M website views per year

At $B M C$, research is always in progress.

Learn more biomedcentral.com/submissions 